ISSN $0258-7122$

Bangladesh J. Agril. Res. 32(3) : 359-368, September 2007

\title{
ISSUES AND OPTIONS IN THE PRODUCTION OF HIGH VALUE CROPS IN COASTAL REGION OF PAKISTAN
}

\author{
Ali Muhammad KhushK $^{1}$ and Muhammad Ibrahim Lashari ${ }^{2}$
}

\begin{abstract}
Primary data from various stakeholders were collected to examine the issues and options in the production of high value crops in coastal region of Pakistan. During 2002, a list of betel leaf and muskmelon growers of Thatta District were developed and out of sampling frame, 160 growers were randomly selected. In the coastal area, growers are engaged in agriculture, fishing, and livestock activities. They keep camel, buffalo, and cattle mainly for milk, which is domestically consumed or sold at village level. The socio-economic conditions of growers living in coastal villages are very poor. Most of the male are unemployed or employed on daily wages. Women are engaged in fish processing industries as unskilled worker and earn a meager income. The analysis of betel leaf and muskmelon was carried out to examine the economic viability of these crops in the coastal region. Analysis shows that these crops have tremendous potential and have no competition in the existing crops in the region. The growers received high net return from betel leaf cultivation and reasonable income from muskmelon cultivation in the coastal region. The major issues for the development of high value crops in the region as identified were high initial cost, poor management operations, low input use, control of insectpests and diseases and lack of knowledge.
\end{abstract}

Key Words: Issues and options, high value crops, coastal region of Pakistan.

\section{Introduction}

Coastal region is one of the most important national economic resources, where highly concentrated socio-economic activities are undertaken which contribute 83 percent of the coastal economy of the country. The communities living in coastal belt are mainly engaged in agriculture, fishing or livestock activities. They keep camels, buffalo, and cattle. Number of households are engaged in the commercial collection of fodder or wood. Some members of these communities are involved in trade and the construction and repair of boats and engines. The communities which live further inland, are engaged mainly in agricultural or livestock activities or a combination of both. Camel grazing in the coastal belt can be subdivided into permanent or near permanent grazing and seasonal grazing. Seasonal grazing takes place during the monsoon seasons in the areas of

${ }^{1 \& 2}$ Technology Transfer Institute, (PARC) ARI, Tandojam, Pakistan. 
mangrove forests by households/communities from the interior. Livestock other than camels, kept by the coastal population are buffaloes, cattle and some small stock, especially sheep and goats. Buffaloes/cattle are kept by agriculturists in areas near the coast and by some of the fishermen, which live within the coastal line. The animals are mainly kept for their milk, which is consumed domestically or sold.

Coastal region is capable of producing crops, livestock, and fisheries resources. Marine fisheries have an immense potential in contributing towards national economic growth and development. However, the present value of various coastal resources will continue to decline if unchecked due to continued coastal degradation particularly from land based activities. There is an economic loss to future generations from the continued degradation of coastal environments and natural system. This will be reflected in loss of agricultural land close to the coast, loss of biodiversity, dislocation of coastal communities, loss of livelihoods, loss of fisheries, pollution of beaches and recreational facilities and decline of coastal ecotourism.

The socio-economic condition of the communities living in various coastal village/settlements is very poor. Falling levels of income are exacerbated by rising level of unemployment caused by the bankruptcy of many fisheries. A study conducted by the Agha Khan Foundation found that upto $47 \%$ of male population of the villages was unemployed, $22.95 \%$ were employed on daily wages, and $7.7 \%$ were self-employed, while only $3.4 \%$ earned a monthly salary. Women were mainly employed in the fish processing industry as unskilled and semi-skilled workers that earned a meager income. The study also report that only $32 \%$ of women were unemployed and more than $65 \%$ earned a monthly income.

Agricultural land is low lying in coastal area frequently subject to severe drainage and soil salinity problems caused by high, more or less saline, watertables, stagnation of rain and runoff water and flooding from rivers or periodic storm surges. There may also be physical damage from wind storms or tidal waves, and sensitivity to airborne salt deposition. Low-lying agricultural lands may also be susceptible to shoreline retreat and flooding as a result of coastal erosion, subsidence or a rise in sea levels which could result from global climatic change. Higher air humidity in coastal areas is favourable to the occurrence and propagation of certain plant diseases and pests that constrain crop growth. Even if the agricultural area is not directly affected, it may be taken over to replace land lost by other sectors. 
Agricultural activities, such as grain crops and livestock grazing tend to be marginalized and replaced, either by non-agricultural activities or by agricultural activities with higher-value outputs, which require higher capital inputs and less land (for example intensive livestock raising or horticulture). Smallholders, unable to invest and intensify, thus tend to lose their land and migrate to the coastal towns. To enhance the socio-economic condition of growers in the coastal area, it is not possible by increasing per acre yield of major crops, but also to produce high value crops. Betel leaf and muskmelon have no competition in the existing crops in the coastal region of Sindh. Therefore, this study was conducted to assess the economic viability of betel leaf and muskmelon cultivation to guide the growers, who intend to grow these crops on commercial basis and it is also be useful for researcher and policy makers to frame a dynamic agricultural policy for the development of such high value crops in the country. Therefore, this study is planned with the following objectives:

\section{Objectives}

$\square$ to examine the existing agronomic practices of betel leaf and muskmelon; and to determine per hectare cost of production at growers' level;

口 to investigate physical productivity per unit of betel leaf and muskmelon to estimate the returns obtained by the growers.

\section{Materials and Method}

The data used in this paper was derived from an in-depth semi-structured interview with informants, during the course of a separate survey of betel leaf and muskmelon growers in coastal area, conducted as part of a broader investigation of the performance of coastal farming system in Sindh province of Pakistan. The data were collected through an exploratory survey in purposively selected areas of Thatta District. This district is the main growing area of betel leaves and muskmelon in the coastal area of Sindh. The members of betel leaf and muskmelon growers were selected as key informants. data were also used from various government agencies and were cross checked with different levels of informants. A list of betel leaf and muskmelon growers were collected from the revenue department and out of sampling frame, 80 growers were randomly selected from each commodity. The total sample size 160 is considered adequate in terms of depth and accuracy resources available for the study. 


\section{Results and Discussion}

\section{Betel leaf cultivation in coastal area}

To assess the economic viability of betel leaf and muskmelon cultivation in the coastal region, the major production operations like land preparation, planting materila, sowing methods, fertilizer, farm yard manure, insect pest and diseases were analyzed and are briefly described here under.

It was found that a good land preparation is necessary for proper and rapid growth of the corp. Sufficient time and labour is required for land preparation for betel leaf cultivation. Normally one deep ploughings carried out for opening the surface and sub soil. After deep ploughings, land is left for few days to get air and sunlight. The next stage is to dig the plant beds, which are done by digging two and half feet beds and filled with canal silt and farmyard manure. Betel leaf planting is usually done either in the months of February-March or June-July. This time is considered most favourable for plant growth and yield. To estimate the distance and mark the place where the plants are to be grown. Take out the soil from a shallow hole in the area of the first marked place. The cuttings of betel leaves are planted in furrows one meter apart having a distance of 10 to 15 $\mathrm{cm}$. The cuttings are covered with paddy straw after planting. Care should be taken to avoid to plant many varieties in one shade. The distance between plants must be maintained properly and spraying of water is very essential which is sprinkled after every 3-4 hours for about 20-30 days. Farm yard manure (FYM) and interculturing of the plants must continue as per the plant requirement. After 6-8 months, these cuttings would be ready for harvesting.

To keep the plant healthy, vigorous and productive, it is necessary to assess the nutritional requirement of the plant. The soil fertility levels in which they are grown need to be maintained. Therefore, growers should regularly apply FYM in the betel leaf field to maintain the fertility level. The manure is properly mixed with the soil and then irrigated. At the time of planting, betel leaf grows normally applied 2 to 3 truck/ha. The use of FYM, soon after interculturing of betel leaf field, as the shape, colour, and size of betel leaf becomes healthier and produce more leaves. The recommendation on fertilizer application for betel leaf cultivation is not available. The average use of fertilizer ranged from 6 to 9 bags ${ }^{1}$ of DAP and 2 to 3 bags of NP or nitrate per hectare during the year. None of the growers has applied urea in the betel leaf. For efficient fertilizer use, attention should be paid to balanced fertilizer dose, appropriate application time, application method, and irrigation quantity.

\footnotetext{
${ }^{1}$ One bag is equal to $50 \mathrm{~kg}$.
} 
The betel leaf is a creeper plant, therefore, it is necessary to prepare shade for the support and protection of the plant. Shade is normally prepared with bamboo splint and other local wood material. Such type of shade is prepared for temporary basis for about 4-5 years. The height of the shade usually maintained about two meters high as the workers can walk inside the shade for watering and other cultural operations. After one month planting cuttings of betel leaf begin to sprout and creep. At this stage, plants are to be trailed with bamboo splint or wood stick. The vines trail upto two meters height and they are lowered down to the ground level and stem is covered with soil. Betel leaf is attacked by number of pests and diseases. The common pests reported are mealy bugs, mites, and aphids. The most common diseases of betel leaf are foot and leaf rot. The efforts have been made to estimate the cost of pesticide applied by the growers in coastal areas. About 5 betel leaf varieties are commonly grown in the study area. Each variety possesses different characteristics i.e., size, shape, colour, and taste. Betel leaf starts production after 8 months of planting. In the beginning, it produces low yield about $30 \mathrm{~kg} / \mathrm{ha}$ from single harvest. Then the yield from single harvest slowly increased and reached the maximum level of $80 \mathrm{~kg} / \mathrm{ha}$. The maximum yield starts from second year and it will continue upto the fourth year. After fourth year, the yield started declining and reached $30 \mathrm{~kg} / \mathrm{ha}$ from single harvest. Moreover, after $5^{\text {th }}$ year, it gives low yield with poor quality leaves and become uneconomical crop. Most of the growers removed the crop after 5 years. Betel leaf growers received price Rs. 250 per kg. Growers usually sell their produce to the wholesaler in the city on fixed rates Rs. $250 \mathrm{~kg}$. They further pointed out that the low quality of leaves mostly produced after fifth year are sold at low price of Rs. $150-200 / \mathrm{kg}$. This was one of the reasons that most of the producers remove their crop after $5^{\text {th }}$ year.

\section{Muskmelon cultivation in coastal area}

Musk melon (Cucumis melo) is a creeping cucurbit with its origin in Iran and Pakistan, but it is also produced in Kashmir and Afghanistan. Muskmelon is a popular crop and has a lot of medicinal values. It is considered as tonic to heart and brain, and is laxative and diuretic. It is good source of Vitamins A, B, and C and poor and rich families equally consume it. It possesses macro and micro nutrients in sufficient quantities. It improves the urinary discharge and its seeds are also used in liver and kidney troubles, throat burning, thirst and chronic fever. All its parts are used including its rind and seed and its outer skin, which contain most of the valuable nutrients. There are a number of varieties of melon in the world but in Pakistan, farmers grow only local varieties, such as Golden and Dharidar. Muskmelon requires more heat than the other cucurbits and its plant 
cannot survive temperature below $20^{\circ} \mathrm{C}$. Hot and dry air and sunshine during the fruiting period are an important factor for development of high sugar and good taste for muskmelon. At the germination time, the optimum temperature required is $27-29^{\circ} \mathrm{C}$. The clay soil is the best for muskmelon cultivation in the areas where crop is not irrigated. In Sindh, muskmelon is mostly cultivated in coastal area. To analyze the profitability of muskmelon in coastal area, the major operations like land preparation, planting period, sowing methods, FYM, fertilizer, insect pest, and disease were analyzed and described here under.

A good land preparation is necessary for proper and rapid growth of muskmelon crop. Normally one deep ploughing is carried out for opening the soil surface. After the deep ploughing, land is left for few days to get air and sunlight. After deep ploughing, growers used gobble 2-3 times, followed by 2-3 cultivations. Timely sowing of muskmelon is an important factor for its rapid and successful growth. Crop sown on proper time, gave best germination of the seeds. There are two crops in a year i.e., winter and summer. Winter crop is main crop cultivated on 70 percent of land. This crop is planted in December-January, which matures in 105 days and gives produce for more than three months. Summer crop is planted in July-August and matured in 60 days. Sowing of muskmelon through drill is common practice among growers. None of growers reported broadcasting of muskmelon. There are two types of drill used by the growers, first drill driven by tractor and second bullock driven drill. Healthy seed is essential for healthy crop and better yield. There is common problem of fungus attack on seed. It is necessary to treat the seed with any fungicide to eliminate the hazard of fungal diseases. Application of farmyard manure is necessary to keep plant healthy, vigorous and productive because it fulfils the nutritional requirements of the plant. The growers usually apply FYM after every three years.

The recommended dose of chemical fertilizer is 5 bags of urea, 5 bags of DAP and 5 bags of potassium sulphate per hectare. However, growers did not follow the recommendations made by agriculture department and mostly used on their own experience. There are number of varieties of muskmelon under cultivation. In the study area, only two local varieties are commonly grown viz. Golden and Dharidar. A number of insect-pests and diseases attack muskmelon. The most common insects were fruit fly, white fly and leaf cutter. The most common disease reported is downey mildew. It was found that growers applied 3 to 6 sprays of pesticides to control the insect-pests.

The yield of muskmelon varied from farm to farm due to number of reasons, such as variation in soils, land preparation, attack of insects-pests and diseases. It 
was also recorded that the yield of summer crop ranged between 7995 and 12000 $\mathrm{kg}$ per hectare, while the yield of winter crop ranged between 15990 and 19995 $\mathrm{kg}$ per hectare. An effort has been made to identify the reasons for low yield of muskmelon in the studied area. The most important feature was identified as low dose of fertilizer as reported by 54 percent growers. Poor land management, old varieties, unsuitable climatic conditions and low use of FYM are major reasons for low yield of muskmelon. There is a wide variation in muskmelon prices during the season, such as alternative fruit bearing, supply \& demand in the market, etc. The price in the early harvest seasion was higher than the mid and late harvest season. In early season, growers received highest price from summer crop Rs. $701 / 40 \mathrm{~kg}$ as compared to Rs. $650 / 40 \mathrm{~kg}$ in winter season. It is clear from the results that the summer crop fetched higher prices than the winter crop.

\section{Economic analysis}

The economic analysis describes the methods used in analyzing economic behaviour and the application of the results obtained to solve economic problem (David, 1979). The most important criteria which is commonly used to analyze efficiency of agricultural enterprises is determination of input output ratio. These criteria were used to determine the economic efficiency of betel leaf and muskmelon enterprise in coastal area in Sindh during 2002.

\section{Fixed costs}

At the initial stage, the main costs involved are land development, labour utilization and input application at the time of planting. Land development includes ploughing, planking, leveling, shade making, and layout of the field. Amongst all, land leveling needs more attention and time. It is found that the fixed cost of betel leaf per hectare was Rs. 487830 and for muskmelon Rs. 26892 and Rs. 18711 for winter and summer crops, respectively.

\section{Variable costs}

The variable cost consists of land management practices including crop inputs i.e., FYM fertilizer, pesticides, irrigation, payments to hired labour for crop production activities. It is found that the variable cost of betel leaf per hectare was Rs. 87625 and for muskmelon Rs. 18338 and Rs. 14925 for winter and summer crops, respectively.

\section{Marketing costs}

Marketing costs of betel leaf include transportation, commission charges of agents who are intermediaries in between producers and sellers of produced and loading/unloading. Survey results indicate that the marketing cost of betel leaf 
per hectare was Rs. 565 and for muskmelon Rs. 52595 and Rs. 30223 for winter and summer crops, respectively, which include transportation, commission charges and loading/unloading charges.

\section{Cost of production}

The total costs can be defined as the fixed cost plus variable costs (Bishop et al., 1958). The total cost of production was determined to appraise input-output relationship. For this purpose, all costs incurred in the betel leaf and muskmelon cultivation by the growers are aggregated and are presented in Table 1.

Table 1. Costs of production by the selected betel leaf and muskmelon growers.

\begin{tabular}{|c|c|c|c|}
\hline \multirow[t]{3}{*}{ Component costs } & \multicolumn{3}{|c|}{ Cost of Rs./hectare } \\
\hline & \multirow[t]{2}{*}{ Betel Leaf } & \multicolumn{2}{|c|}{ Muskmelon } \\
\hline & & Winter crop & Summer crop \\
\hline \multicolumn{4}{|l|}{ a) Fixed costs } \\
\hline Land development & 8080 & 8892 & 6711 \\
\hline Labour utilization & & 18000 & 12000 \\
\hline Labour cost of planting & 1000 & & \\
\hline Cost of betel leaf plants & 312500 & & \\
\hline Shade making. & 166250 & & \\
\hline Total initial costs & 487830 & 26892 & 18711 \\
\hline \multicolumn{4}{|l|}{ b) Variable cost } \\
\hline FYm & 10400 & 2500 & 2500 \\
\hline Fertilizer & 6525 & 5850 & 5850 \\
\hline Irrigation & 8125 & 200 & 200 \\
\hline Pesticide & 7480 & 4940 & 2470 \\
\hline Interculturing & 15240 & 741 & 741 \\
\hline Pruning/trailing & 3315 & & \\
\hline Seed & & 1976 & 1976 \\
\hline Harvesting charges & 36540 & 2131 & 1188 \\
\hline Total variable cost & 87625 & 18338 & 14925 \\
\hline \multicolumn{4}{|l|}{ c) Marketing costs } \\
\hline Cost of crate & & 10660 & 5940 \\
\hline Grading cost & & 533 & 440 \\
\hline Packing cost & & 1066 & 594 \\
\hline Loading/Unloading & 110 & 1066 & 594 \\
\hline Transportation charges & 215 & 26650 & 14850 \\
\hline Commission charges & 240 & 12600 & 7805 \\
\hline Total marketing costs & 565 & 52595 & 30223 \\
\hline Total $a+b+c:$ & 576585 & 97825 & 63859 \\
\hline
\end{tabular}

\section{Economic analysis}

The economic analysis of betel leaf and muskmelon was worked out and presented in Table II. The results show that growers received high net return from the betel leaf cultivation and reasonable net return from muskmelon 
cultivation. It was observed that progressive growers are particularly attached with betel leaf and muskmelon cultivation in coastal region, because of its high initial cost.

Table 2. Net return per hectare of selected betel leaf and muskmelon growers.

\begin{tabular}{l|l|c|c}
\hline \multirow{2}{*}{ Revenue Productivity } & \multirow{2}{*}{ Betel Leaf } & \multicolumn{2}{|c}{ Muskmelon } \\
\cline { 3 - 4 } & & Winter crop & Summer crop \\
\hline Quantity sold (kg/ha) & 5850 & 15990 & 8910 \\
Price per unit & 250 & 11.33 & 12.66 \\
Gross return & 1462500 & 181166.70 & 112800.60 \\
Gross margin & 885915 & 83341.70 & 48941.60 \\
Cost benefit ratio & $2.54: 1$ & $1.85: 1$ & $1.77: 1$ \\
\hline
\end{tabular}

\section{Conclusion and recommendations}

The major constraints in the production of high value crops in coastal area identified were high initial cost, poor management operations, low input use and control of insects, pests and diseases, and lack of knowledge among growers. In fact, these crops have a tremendous scope in the coastal area for future development and expansion. The major inputs, such as irrigation, FYM, pesticide sprays fertilizer and uses of labour are under utilized, affecting betel leaf potential yield. The growers do not know the advantages of timely sowing and adequate use of inputs. The use of chemical sprays and labour appear to be limited by the available resources with growers. It is, therefore, suggested that proper dose of fertilizer, timely use of pesticide sprays, improvement in the management operations are essential to achieve better crop yield.

There is need to improve the existing information system and focus should be given to disseminate production technology among betel leaf and muskmelon growers. There is a need to introduce modern technology particularly in shade preparation. There is need to educate growers and show them why their net return are reduced by not adopting modern technology. This can be used for interculturing, pruning, trailing operations at the farm level by using exportable equipment (as observed in some places in India in betel leaf orchard). Given the difficulties in research and extension services it may be best to target such efforts at farm level.

The lack of finance is also a main constraint among growers in coastal region of Pakistan. There is need to arrange adequate credit facilities at low interest rate. There is a need to maintain the soil fertility through the organic and inorganic sources. In this connection, growers seek guidance from local available resources, such as research stations, extension agents and progressive growers of the locality. The timely and proper application of FYM and chemical fertilizers 
and pesticide sprays to control the insects pests and diseases are important to achieve better crop yield.

\section{References}

Barnett, V. 1991. Sample Survey Principles and Methods. London, Edward Arnold Publisher Ltd.

Bishop, C.E. and W.D Toussaint., 1958. Introduction to Agricultural Economics Analysis, Toppan Printing Ltd, Tokyo, Japan, pp 70.

David, S. 1979. Economic analysis and Canadian policy (Third Ed.). Butter Worth and Co. Ltd. Torossnto Canada pp. 13-4.

IUCN. 2003. Regional technical assistance for coastal and marine resources management and poverty reduction in South Asia. Asian Dev. Bank. The World Conservation Union, Pakistan. 